\title{
FACTORS INFLUENCING DIRECT COSTS DYNAMICS OF BUILDING PROJECTS - TEAM MEMBERS PERCEPTION IN DELTA STATE, NIGERIA *UJENE, A.0., ${ }^{1}$ IDORO, G.I. ${ }^{2}$ and MBAMALI, I. ${ }^{3}$ \\ http://dx.doi.org/10.4314/ejesm.v6i5.10
}

Received 21st May 2013; accepted 16th August 2013

\begin{abstract}
Inaccurate costs forecast of building projects is traceable to variation in direct and indirect costs caused by several factors. This study evaluates the severity of the impact of eighty factors responsible for direct costs dynamics of building projects in Delta State, Nigeria. The objective is to compare consultants and contractors perception of the severity of the factors on direct costs differential. A field survey of 85 contractors and 67 consultants was conducted with the aid of structured questionnaires. Data were analysed using mean score, Mann-Whitney $U$ and Kruskal Wallis tests. The study concludes that consultants and contractors have similar perception of the effect of the direct cost variation factors (p-values between 0.365 and 0.930). Construction, resources, and performance factors are the most significant of the groups (MS range $=3.66$ to 4.33), though no significant variation among groups' importance in the evaluation ( $p$-values $=0.42$ and 0.19). The study recommends that clients should count on consultants and contractors for direct cost advice, provided they accommodate all the direct cost variation groups during cost advice, with priority on the leading factors of each group.
\end{abstract}

Key words: Building projects, Consultants, Contractors, Cost dynamics, Direct costs.

\section{Introduction}

Buildings provide accommodation for man and his activities in the built environment and cost is one of the foremost criteria of their construction success (Memon et al., 2010). Cost consideration is more critical because, clients usually pay for unbudgeted increase in project costs (Amusan, 2011). Building costs are incurred by a contractor in carrying out works and its elements include labour, material, plant and machinery costs and other expenses, categorised into direct and indirect costs. Direct costs are traceable to an activity/work item, contributing enormously (between 65\% and 93\%) to total project costs (Chitkara, 2006). Poor cost management leads to cost overrun, delay, abandonment, profit loss, contractors' bankruptcy and insolvency, quality loss, clients' dissatisfaction and disputes (Ujene, 2012).

Studies showed that labour costs vary between $20 \%$ and $90 \%$, while material costs vary between $10 \%$ and $80 \%$ among building trades (Ayeni, 1997). In building elements, material costs vary between $42 \%$ and $77 \%$, while labour costs vary between $23 \%$ and $58 \%$ (Achuenu and Ujene, 2006). The causes of cost dynamics between projects and regions can be exposed by

${ }^{1}$ Department of Building, University of Uyo, Uyo, Nigeria.

${ }^{2}$ Department of Building, University of Lagos, Akoka, Lagos,

Nigeria.

${ }^{3}$ Department of Building, Ahmadu Bello University, Zaria,

Nigeria.

*Corresponding author: ujenetony@yahoo.com
(2006) attributed poor cost prediction to cost advisers' inadequate knowledge of the dynamics and value of construction cost influenced by several factors. Therefore, eighty cost variation factors were sourced from studies on factors influencing construction costs by Al-juwaira (1997), Eshofonie (2008), Memon et al. (2010), Ganiyu and Zubairu (2010), Amusan (2011) and others.

This study in view of improving construction costs management, examines factors responsible for direct cost variation of building projects. The objectives are to evaluate and compare consultants and contractors' perception of the effects of the factors on dynamics of direct costs and evaluate the variation in effect among the group of direct cost variation factors. Two hypotheses were postulated to test difference between the perceptions of the consultants and contractors of the effect of the factors on direct costs and among groups of variation factors in Delta state.

Delta state is located within latitudes $5^{\circ} 00^{\prime} \mathrm{N}$, $6^{\circ} 30^{\prime}$ and longitudes $5^{\circ} 00^{\prime} \mathrm{E}, 6^{\circ} 45^{\prime} \mathrm{E}$. The landscape is dotted with many oil wells and transversed by oil pipelines which in addition to population pressure affect the traditional occupations of the people -farming, fishing (Igben, 2009). The restiveness in the area is partly linked with youth's agitation for 
sustainable development arising from lack of infrastructural development (Abraham, 2011).
The location of Delta State in Nigeria is shown in Figure 1.

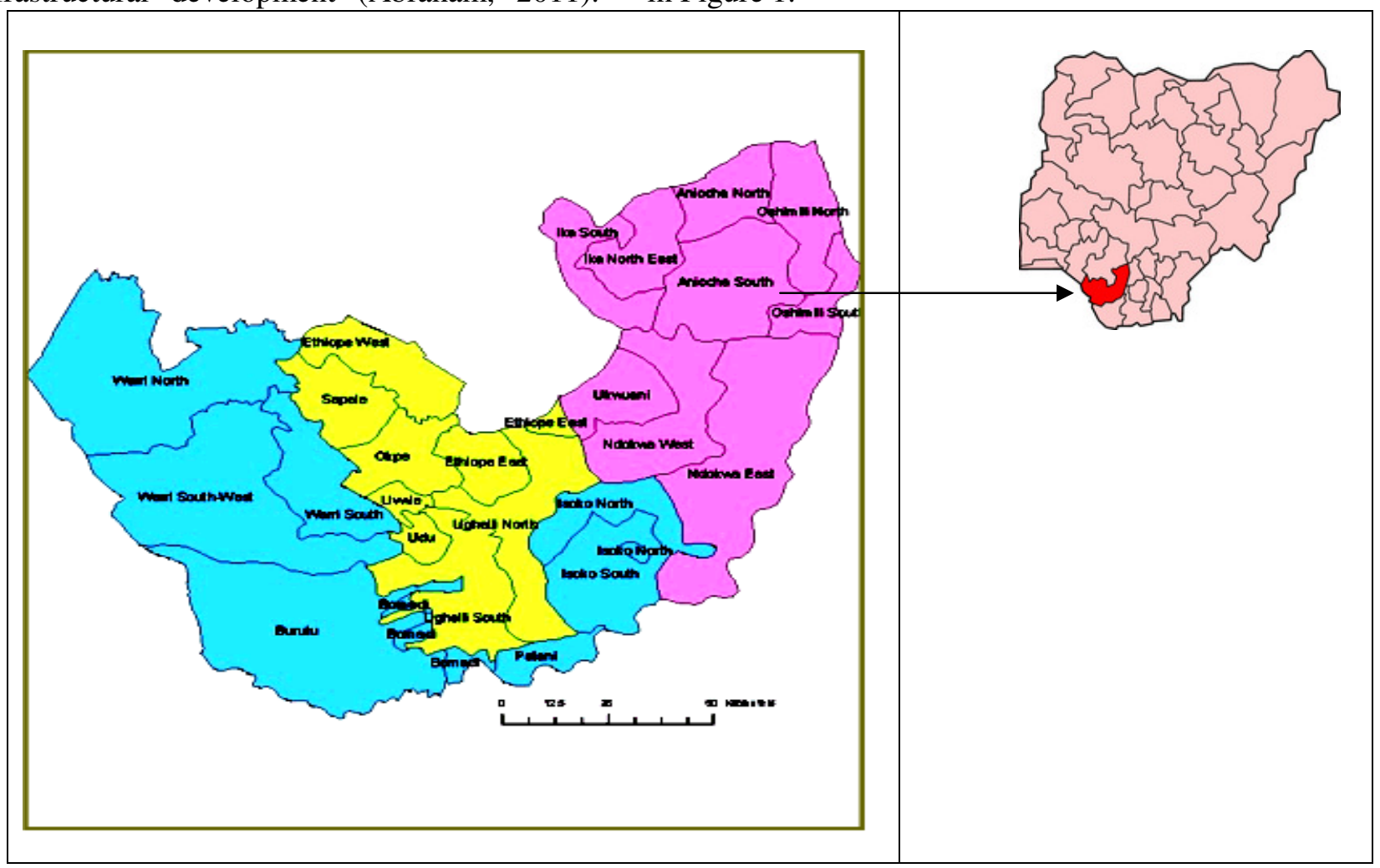

Figure 1 Location of Delta State in Nigeria

\section{Methodology}

This study adopted exploratory survey design approach using structured questionnaires. The population of the study comprises small and medium size contractors and consultants involved in the construction of public buildings. 108 contractors and 81 consultants were established through a pilot survey and adopted as the study population, then 85 contractors and 67 consultants were randomly sampled resulting in 78 and 63 valid questionnaires respectively.

Eighty cost variation factors were identified from literature and grouped under ten direct cost variation groups. The effect of each factor on variation in direct costs was measured on a five point Likert-scale namely: nil $=1, \quad$ low $=2$, moderate $=3$, high $=4$ and very high $=5$.

Data collected were processed using Statistics Package for Social Sciences (SPSS) version 17, to obtain the Mean Score (MS). The difference between the perceptions of consultants and contractors and the difference in effect among the groups of variation factors were analysed using Mann Whitney U and Kruskal Wallis tests respectively.

\section{Results \\ Effects of Environmental Factors}

The effect of twenty environmental factors on variation in direct costs were analysed using Mean Score (MS). The results are presented in Table 1 and it shows that consultants and contractors perceive that, site condition, location of site and poor production of raw materials by the country ranked first, second and third respectively. The three factors have respective MS of 4.62, 4.27 and 4.16 according to the consultants, while the MS were 4.45, 4.31 and 4.21 by contractors' perception. The results indicate that among the environmental factors, natural disaster ranked last with MS of 2.19 and 2.33 as perceived by consultants and contractors respectively.

\section{Effects of Construction Parties Factors}

The results of the effect of twelve construction parties' factors on variation in direct costs are presented in Table 2 and it shows that consultants and contractors perceive that incorrect planning and poor financial control on site ranked first and second respectively with MS range between 4.81 and 4.45. Contractors ranked contractors type/size, contractors' previous experience and poor supervision in third, fourth and fifth position 
with MS of 4.38, 4.08 and 4.00 respectively, while the consultants ranked the factors tenth and duo third with respective means of 2.81 and
4.11. Level of IT utilization and disputes on site ranked last among the construction parties factors with MS range between 2.64 and 2.32.

Table 1 Team-members perceptions of environmental factors

\begin{tabular}{llllllll}
\hline & \multicolumn{3}{l}{ Consultants $(\mathrm{N}=63)$} & \multicolumn{3}{l}{ Contractors (N=78) } \\
Environmental Factors & Sum & MS & Rank & Sum & MS & Rank \\
\hline Site condition & 291 & 4.62 & 1 & 347 & 4.45 & 1 \\
Site location & 269 & 4.27 & 2 & 336 & 4.31 & 2 \\
Poor raw materials production & 262 & 4.16 & 3 & 328 & 4.21 & 3 \\
Fraudulent practices and kickbacks & 224 & 3.56 & 8 & 312 & 4.00 & 4 \\
High transportation cost & 258 & 4.10 & 5 & 301 & 3.86 & 5 \\
Economic stability & 240 & 3.81 & 6 & 294 & 3.77 & 6 \\
Absence of Construction-cost data & 237 & 3.76 & 7 & 292 & 3.74 & 7 \\
No of construction on going & 224 & 3.56 & 8 & 291 & 3.73 & 8 \\
Weather effect & 218 & 3.46 & 10 & 271 & 3.47 & 9 \\
Youth and community activity & 213 & 3.38 & 12 & 267 & 3.42 & 10 \\
Access to basic infrastructure & 215 & 3.41 & 11 & 267 & 3.42 & 10 \\
Level of competition & 213 & 3.38 & 12 & 265 & 3.40 & 12 \\
Effect of oil exploration & 209 & 3.32 & 15 & 263 & 3.37 & 13 \\
Government policies & 213 & 3.38 & 12 & 259 & 3.32 & 14 \\
Supplier manipulation & 202 & 3.21 & 18 & 250 & 3.21 & 15 \\
Labour unions activities & 205 & 3.25 & 17 & 250 & 3.21 & 15 \\
Social cultural impacts & 186 & 2.95 & 19 & 236 & 3.03 & 17 \\
Foreign firms' influence & 261 & 4.14 & 4 & 231 & 2.96 & 18 \\
Lack of productivity standard & 208 & 3.30 & 16 & 203 & 2.60 & 19 \\
Natural Disaster & 138 & 2.19 & 20 & 182 & 2.33 & 20 \\
\hline
\end{tabular}

Table 2 Team-members perceptions of construction parties' factors

\begin{tabular}{lllllll}
\hline & \multicolumn{3}{c}{ Consultants (N=63) } & \multicolumn{3}{l}{ Contractors (N=78) } \\
Construction Parties Factors & Sum & MS & Rank & Sum & MS & Rank \\
\hline Incorrect planning & 303 & 4.81 & 1 & 373 & 4.78 & 1 \\
Poor financial control & 285 & 4.52 & 2 & 349 & 4.47 & 2 \\
Contractors type/size & 177 & 2.81 & 10 & 342 & 4.38 & 3 \\
Contractor's previous experience & 259 & 4.11 & 3 & 318 & 4.08 & 4 \\
Poor supervision & 259 & 4.11 & 3 & 312 & 4.00 & 5 \\
Client type & 234 & 3.71 & 5 & 293 & 3.76 & 6 \\
Cost estimate reliability & 224 & 3.56 & 6 & 278 & 3.56 & 7 \\
Poor coordination between designers \& contractors & 206 & 3.27 & 8 & 251 & 3.22 & 8 \\
Management - labour relationship & 182 & 2.89 & 9 & 226 & 2.90 & 9 \\
Consultants type & 213 & 3.38 & 7 & 212 & 2.72 & 10 \\
Level of IT utilization & 158 & 2.51 & 11 & 206 & 2.64 & 11 \\
Disputes on site & 146 & 2.32 & 12 & 202 & 2.59 & 12 \\
\hline
\end{tabular}




\section{Effects of Macro-economic Factors}

The results of the effect of nine macroeconomic factors on direct costs are presented in Table 3. Table 3 shows that contractors perceive that interest rates, exchange rates and inflation ranked first, second and third with respective mean scores of $4.77,4.53$ and 4.49 , while the order according to the consultants were, inflation (4.81), exchange rates (4.60) and interest rates (4.48). Consultants and contractors ranked money supply, national output and unemployment among the least with mean scores range between 2.78 and 1.78 .

\section{Effects of Design Factors}

The results of the effect of eight design factors on variation in direct costs are presented in Table 4 and it shows that consultants and contractors perceive that floor area, specification/design error, number of floors and average storey height ranked first, second, third and fourth respectively among the design factors with mean scores range between 4.41 and 3.84, while contractors ranked circulation space last with mean score of 2.37, consultants ranked plan shape last with mean score of 2.38 .

Table 3 Team-members perceptions of macro-economic factors

\begin{tabular}{lllllll}
\hline & \multicolumn{3}{c}{ consultants (N=63) } & \multicolumn{3}{c}{ Contractors (N=78) } \\
Macro-Economic Factors & Sum & MS & Rank & Sum & MS & Rank \\
\hline Interest Rates & 282 & 4.48 & 3 & 372 & 4.77 & 1 \\
Exchange Rates & 290 & 4.60 & 2 & 353 & 4.53 & 2 \\
Inflation & 303 & 4.81 & 1 & 350 & 4.49 & 3 \\
Import duties and tariffs & 277 & 4.40 & 4 & 287 & 3.68 & 4 \\
Wage Rates & 231 & 3.67 & 5 & 287 & 3.68 & 4 \\
National disposable income & 216 & 3.43 & 6 & 261 & 3.35 & 6 \\
Money supply & 172 & 2.73 & 8 & 217 & 2.78 & 7 \\
National Output & 183 & 2.90 & 7 & 213 & 2.73 & 8 \\
Unemployment & 112 & 1.78 & 9 & 163 & 2.09 & 9 \\
\hline
\end{tabular}

Table 4 Team-members perceptions of design factors

\begin{tabular}{lllllll}
\hline & \multicolumn{3}{c}{ consultants (N=63) } & \multicolumn{3}{c}{ Contractors (N=78) } \\
Design Factors & Sum & MS & Rank & Sum & MS & Rank \\
\hline Floor area & 278 & 4.41 & 1 & 343 & 4.40 & 1 \\
Specification/design error & 267 & 4.24 & 2 & 333 & 4.27 & 2 \\
Number of floors & 266 & 4.22 & 3 & 327 & 4.19 & 3 \\
Storey height & 242 & 3.84 & 4 & 304 & 3.90 & 4 \\
Type of services & 210 & 3.33 & 6 & 256 & 3.28 & 5 \\
Building type & 178 & 2.83 & 7 & 221 & 2.83 & 6 \\
Plan shape & 150 & 2.38 & 8 & 201 & 2.58 & 7 \\
circulation space & 213 & 3.38 & 5 & 185 & 2.37 & 8 \\
\hline
\end{tabular}

\section{Effects of Procurement Factors}

The results of the effect of seven procurement related factors on direct costs variation are presented in Table 5 and it shows that consultants and contractors perceive that traditional method, construction management, management contracting, and project management method ranked first, second, third and fourth respectively with MS varying between 3.86 and 3.17. The duo also perceived that design and build ranked last among the procurement methods.

\section{Effects of Resources Factors}

The results of the effect of five resources related factors on direct costs variation are presented in Table 6 and it shows that consultants and contractors perceive that, material availability, fluctuation of prices and machinery maintenance problems ranked first, second and third respectively with MS range between 4.46 and 3.72, while both perceived that availability of labour ranked least among the resource factors. 
Table 5 Team-members perceptions of procurement factors

\begin{tabular}{llllllll}
\hline & \multicolumn{3}{c}{ consultants (N=63), } & \multicolumn{3}{c}{ contractors (N=78) } \\
& Sum & MS & Rank & Sum & MS & Rank \\
\hline Procurement Factors & 243 & 3.86 & 1 & 299 & 3.83 & 1 \\
Construction management & 216 & 3.43 & 2 & 272 & 3.49 & 2 \\
Management contracting & 200 & 3.17 & 3 & 253 & 3.24 & 3 \\
Project management method & 200 & 3.17 & 3 & 250 & 3.21 & 4 \\
Labour only method & 178 & 2.83 & 6 & 238 & 3.05 & 5 \\
Direct labour method & 187 & 2.97 & 5 & 235 & 3.01 & 6 \\
Design and build & 166 & 2.63 & 7 & 215 & 2.76 & 7 \\
\hline
\end{tabular}

Table 6 Team-members perceptions of resources factors

\begin{tabular}{llllllll}
\hline & \multicolumn{3}{c}{ Consultants (N=63), } & \multicolumn{4}{c}{ contractors (N=78) } \\
Resources Factors & Sum & MS & Rank & Sum & MS & Rank \\
\hline Materials availability & 281 & 4.46 & 1 & 346 & 4.44 & 1 \\
Fluctuation of prices & 274 & 4.35 & 2 & 341 & 4.37 & 2 \\
Machinery maintenance problems & 238 & 3.78 & 3 & 290 & 3.72 & 3 \\
Availability of machinery & 176 & 2.79 & 4 & 232 & 2.97 & 4 \\
Availability of labour & 163 & 2.59 & 5 & 219 & 2.81 & 5 \\
\hline
\end{tabular}

\section{Effects of Construction Factors}

The results of the effect of four construction factors on direct costs variation are presented in Table 7. The consultants and contractors perceive that construction method has the highest influence among the construction factors with MS of 4.67 and 4.68 respectively. However, while the consultants ranked rework/ construction error and additional work/ variation order in third and second position with MS of 3.68 and 4.41 respectively, the contractors ranked the two factors in the second and third position with MS of 4.63 and 4.45 respectively. The result also shows that consultants and contractors perceive that waste generation level ranked last with MS of 3.51 and 3.56.

Table 7 Team-members perceptions of construction factors

\begin{tabular}{llllllll}
\hline \multirow{2}{*}{ Construction Factors } & \multicolumn{3}{c}{ Consultants (N=63), } & \multicolumn{3}{c}{ contractors (N=78) } \\
& Sum & MS & Rank & Sum & MS & Rank \\
\hline Construction methods & 294 & 4.67 & 1 & 365 & 4.68 & 1 \\
Rework/ construction error & 232 & 3.68 & 3 & 361 & 4.63 & 2 \\
Additional work/ variation order & 278 & 4.41 & 2 & 347 & 4.45 & 3 \\
Waste generation level & 221 & 3.51 & 4 & 278 & 3.56 & 4 \\
\hline
\end{tabular}

\section{Effects of Financing Factors}

The results of the effect of four financing factors on direct costs variation are presented in Table 8. The consultants perceive that government finance, formal private sector finance and public - private finance ranked first, second and third with respective MS of 3.71, 3.48 and 3.17 , while the contractors perceived that the first two factors equally ranked first with MS of 3.53, public - private finance ranked third with MS of 3.24. Informal private sector financed and developers/contractors financed ranked fourth and fifth with MS range between 3.03 and 2.84 .

\section{Effects of Performance Factors}

The results of the effect of four performance factors on variation in direct costs are presented in Table 9 and it shows that consultants and contractors perceive that duration of contract period, quality requirement and productivity requirement ranked first, second and third respectively with MS ranging between 4.63 and 4.01. The result also shows that contract sum requirement and users' requirement ranked fifth and sixth respectively with MS ranging between 3.41 and 3.32 among the performance factors. 
Table 8 Team-members perceptions of financing factors

\begin{tabular}{llllllll}
\hline & \multicolumn{3}{c}{ Consultants (N=63), } & \multicolumn{3}{c}{ Contractors (N=78) } \\
Financing Factors & Sum & MS & Rank & Sum & MS & Rank \\
\hline Government finance & 234 & 3.71 & 1 & 275 & 3.53 & 1 \\
Formal private sector financed & 219 & 3.48 & 2 & 275 & 3.53 & 1 \\
Public - private financed & 200 & 3.17 & 3 & 253 & 3.24 & 3 \\
Informal private sector financed & 191 & 3.03 & 4 & 240 & 3.08 & 4 \\
Developers/Contractors financed & 179 & 2.84 & 5 & 227 & 2.91 & 5 \\
\hline
\end{tabular}

Table 9 Team-members perceptions of performance factors

\begin{tabular}{llllllll}
\hline & \multicolumn{3}{c}{ Consultants $(\mathrm{N}=63)}$, & \multicolumn{3}{c}{ Contractors (N=78) } \\
Performance Factors & Sum & MS & Rank & Sum & MS & Rank \\
\hline Contract duration & 290 & 4.60 & 1 & 361 & 4.63 & 1 \\
Quality requirement & 282 & 4.48 & 2 & 348 & 4.46 & 2 \\
Productivity requirement & 253 & 4.02 & 3 & 313 & 4.01 & 3 \\
Health and safety requirement & 241 & 3.83 & 4 & 298 & 3.82 & 4 \\
Contract sum requirement & 209 & 3.32 & 5 & 266 & 3.41 & 5 \\
Users requirement & 208 & 3.30 & 6 & 263 & 3.37 & 6 \\
\hline
\end{tabular}

\section{Effects of Tendering Factors}

The results of the effect of four tendering factors on variation in direct costs are presented in Table 10. The consultants perceive that contractual procedure and bureaucracy in tendering method ranked first and second with MS of 4.41 and 3.40 respectively, while time lag between design and tendering ranked last with MS of 2.97. The contractors perceived that bureaucracy in tendering method and time lag between design and tendering ranked first and second with MS of 3.51 and 3.17 respectively, while contractual procedure ranked last with MS of 2.85 among the tendering factors.

\section{Significance of Cost Variation Group Factors}

For the purpose of evaluating the significance of the cost variation groups, the mean of mean scores were computed and ranked for each group. The result is shown in Table 11 . This table shows that consultants and contractors perceived that construction factors have the most significant effect, ranking first with MS of 4.07 and 4.33. Consultants perceived that resources and performance factors ranked second and third with MS of 3.97 and 3.93 respectively, while the contractors ranked performance and resources factors second and third with MS of 3.95 and 3.66 respectively. The result further shows that financing and procurement factors were ranked last by consultants with MS of 3.25 and 3.15 respectively, while the contractor ranked procurement and tendering factors last with MS of 3.23 and 3.16 respectively.

Table 10 Team-members perceptions of tendering factors

\begin{tabular}{llllllll}
\hline & \multicolumn{3}{c}{ Consultants $(\mathrm{N}=63)}$, & \multicolumn{4}{c}{ Contractors (N=78) } \\
Tendering Factors & Sum & MS & Rank & Sum & MS & Rank \\
\hline Tendering bureaucracy & 214 & 3.40 & 2 & 276 & 3.54 & 1 \\
Time lag between design and tendering & 187 & 2.97 & 4 & 247 & 3.17 & 2 \\
Insurance cost & 193 & 3.06 & 3 & 239 & 3.06 & 3 \\
Contractual procedure & 278 & 4.41 & 1 & 222 & 2.85 & 4 \\
\hline
\end{tabular}


Table 11 Team-members' perceptions of cost variation groups

\begin{tabular}{lllllllll}
\hline \multirow{2}{*}{ Groups } & \multicolumn{2}{l}{ Consultants } & \multicolumn{7}{c}{ Contractors } \\
& $\mathrm{N}$ & Sum & MS & Rank & N & Sum & MS & Rank \\
\hline CONSTRUCTION-FACTORS & 4 & 16.27 & 4.07 & 1 & 4 & 17.32 & 4.33 & 1 \\
PERFORMANCE-FACTORS & 6 & 23.55 & 3.93 & 3 & 6 & 23.70 & 3.95 & 2 \\
RESOURCES-FACTORS & 5 & 17.97 & 3.97 & 2 & 5 & 18.31 & 3.66 & 3 \\
CONSTRUCTION PARTIES-FACTORS & 12 & 42.01 & 3.50 & 7 & 12 & 43.10 & 3.59 & 4 \\
MACRO-ECONOMIC-FACTORS & 9 & 32.81 & 3.64 & 4 & 9 & 32.10 & 3.57 & 5 \\
ENVIRONMENTAL-FACTORS & 20 & 71.21 & 3.56 & 6 & 20 & 69.81 & 3.49 & 6 \\
DESIGN-FACTORS & 8 & 26.63 & 3.58 & 5 & 8 & 27.82 & 3.48 & 7 \\
FINANCING-FACTORS & 5 & 16.23 & 3.25 & 9 & 5 & 16.29 & 3.26 & 8 \\
PROCUREMENT-FACTORS & 7 & 22.06 & 3.15 & 10 & 7 & 22.59 & 3.23 & 9 \\
TENDERING-FACTORS & 4 & 13.84 & 3.46 & 8 & 4 & 12.62 & 3.16 & 10 \\
\hline
\end{tabular}

Team-members' perception of direct cost variation groups

In order to ascertain whether significant difference exist in the perceptions of the two categories of team members, the first research hypothesis was postulated. It states that there is no significantly difference in the perceptions of consultants and contractors on the effects of factors affecting variation in direct costs. The hypothesis was tested using Mann-Whitney U test at $p \leq 0.05$. The decision rule is that if $p$-value $>0.05$, the test accepts the hypothesis but if $\mathrm{p}$ value $\leq 0.05$, the test rejects the hypothesis. The results are presented in Table 12.

Table 12 shows that the p-values range between 0.365 and $0.930>0.05$ for all the cost variation groups this implies acceptance of the hypothesis that there is no significant difference between the perception of consultants and contractors. This result is an indication that the consultants and contractors have a common opinion regarding the influence of these factors on direct costs.

\section{Effect of direct cost among cost variation groups}

In order to ascertain if significant differences exist in effect among the cost variation groups, the second hypothesis was postulated. It states that the effects of the factors on direct costs do not significantly vary among cost variation groups. This was tested using Kruskal Wallis test at $\mathrm{p} \leq 0.05$. The decision rule is that if $\mathrm{p}$-value $>$ 0.05 , the hypothesis is accepted, but if p-value $\leq$ 0.05 , the hypothesis is rejected. The results are presented in Table 13.

Table 12 Results of Mann Whitney U Test

\begin{tabular}{llllllll}
\hline & $\mathrm{N}$ & $\begin{array}{l}\text { Consultants } \\
\text { Mean } \\
\text { Rank }\end{array}$ & $\begin{array}{l}\text { Contractors } \\
\text { Mean Rank }\end{array}$ & U-value & p-value & $\begin{array}{l}\text { sig. } \\
\text { level }\end{array}$ & Decision \\
Groups & & & & & & & \\
\hline CONSTRUCTION-FACTORS & 12 & 12.21 & 12.79 & 68.5 & 0.840 & 0.05 & Accept \\
PERFORMANCE-FACTORS & 6 & 6.33 & 6.67 & 17.0 & 0.873 & 0.05 & Accept \\
RESOURCES-FACTORS & 5 & 5.20 & 5.80 & 11.0 & 0.754 & 0.05 & Accept \\
CONSTRUCTION PARTIES-FACTORS & 4 & 3.75 & 5.25 & 5.0 & 0.386 & 0.05 & Accept \\
MACRO-ECONOMIC-FACTORS & 9 & 9.61 & 9.39 & 39.0 & 0.930 & 0.05 & Accept \\
ENVIRONMENTAL-FACTORS & 20 & 21.08 & 19.93 & 188.50 & 0.576 & 0.05 & Accept \\
DESIGN-FACTORS & 8 & 8.94 & 8.06 & 28.50 & 0.713 & 0.05 & Accept \\
FINANCING-FACTORS & 5 & 5.20 & 5.80 & 11.0 & 0.753 & 0.05 & Accept \\
PROCUREMENT-FACTORS & 7 & 6.86 & 8.14 & 20.00 & 0.565 & 0.05 & Accept \\
TENDERING-FACTORS & 4 & 4.88 & 4.13 & 6.50 & 0.663 & 0.05 & Accept \\
\hline
\end{tabular}


Factors Influencing Direct Costs Dynamics of Building Projects................UJENE et al.

Table 13 Results of Kruskal Wallis Test

\begin{tabular}{lllllllllllll}
\hline $\begin{array}{l}\text { Team } \\
\text { member }\end{array}$ & $\mathrm{N}$ & min & max & $\begin{array}{l}\text { Group } \\
\text { mean }\end{array}$ & $\begin{array}{l}\text { Group } \\
\text { STD }\end{array}$ & Mean & STD & DF & $\begin{array}{l}\text { p- } \\
\text { value }\end{array}$ & $\mathrm{X}_{\text {CAL }}^{2}$ & $\mathrm{X}_{\text {TAB }}^{2}$ & Decision \\
\hline Consultants 80 & 1.78 & 4.81 & 4.13 & 2.92 & 3.55 & 0.68 & 9 & 0.42 & 9.25 & 16.92 & Accept \\
Contractors & 80 & 2.09 & 4.78 & 4.13 & 2.92 & 3.55 & 0.66 & 9 & 0.19 & 12.52 & 16.92 & Accept \\
\hline
\end{tabular}

Table 13 shows that $\mathrm{p}$-value of $0.42>0.05$ implies acceptance of the first hypothesis. This indicates that the consultants perceive that all the variation groups have significant influence on direct costs dynamics. Table 13 also shows that p-value of $0.19>0.05$ implies acceptance of the second hypothesis. This designates that the contractors also perceive that all variation groups have significant influence on the dynamics of direct costs.

\section{Discussion}

The result of the effect of environmental factors on direct costs variation shows that, site condition and location of site have the most significant effect. This study somehow agrees with Memon et al. (2010), which identified unforeseen ground condition as important factor affecting construction costs. The importance of this factor may be connected to the varying characteristics of sites and ground conditions in the study area. Among construction parties' factors, incorrect planning and poor financial control are the most significant factors, this is similar to the findings of Amusan (2011) which ranked planning first among the factors affecting construction costs, while Eshofonie (2008) ranked it second most significant factor. The result also agree with Azhar et al. (2008), that cost overrun problems are caused by ineffective construction management and poorly established cost control systems. The influence of this factor may be connected with the varying degree of capability and awareness of production planning and cost control systems by team members. The result of the effect of macro-economic factors shows that interest rates, exchange rates and inflation have the most significant effect on direct cost dynamics. The result agrees with that of Osei-Tutu and Adjei-Kumi (2002) and Memon et al. (2010). The significance of interest rate may be consequent upon the high dependence of majority of the contractors on loans from banks for finance which often attract high interest rates, while the effect of inflation may be due to ever increasing and uncertain price levels.

The result of the design factors shows that floor area, specification/design error and number of floors have most significant effect on direct cost changes. This agrees with the observation by Drew et al. (2001) that the behaviour of contractors both in bidding and construction depend greatly on the type and size of the building directly related to floor area and number of floors. Among the resources factors, material availability and fluctuation of prices were most significant. The study also shows that construction method has the highest influence among the construction factors. This is similar to the level of construction complexity identified by Ganiyu and Zubairu (2010), the influence of which may be connected to slow response to mechanisation of construction operations (Ameh and Shokumbi, 2013).

Among the performance factors, contract duration, quality requirement and productivity requirement were most significant. Contractual procedure and bureaucracy in tendering method were also most significant among the tendering factors.

The result of the evaluation of the significance of the cost variation groups shows that construction, resources, and performance factors have the most significant effect on cost dynamics; this implies that team-members should place emphasis on these groups during cost management. The result of the comparison of perceptions of the two project team-members on variation in direct costs shows that the difference in perception is not significant. This result indicates that the team-members have common opinion about the effect of the cost variation factor. This can instil confidence and enhance greater synergy among stakeholders. The result of the evaluation of the differences in effect among the cost variation group shows that team-members perceive that the difference in effect is not significant. This indicates that stakeholders should consider all the groups in their effort to forecast and control direct costs. 


\section{Conclusion and Recommendation}

The study identified ten groups of direct costs variation factors and established the factors among each group which most significantly affect direct costs of building projects. Some established factors were found to be similar to those found in previous works which did not focus specifically on direct cost. The result of the evaluation of the significance of the cost variation groups shows that construction, resources, and performance factors have the most significant effect on cost dynamics. The result of the first hypothesis shows that there is no significant difference in the perceptions of the consultant and contractors indicating that the team-members have common opinion of the effect of the direct cost variation factors.

The result of the second hypothesis shows that team-members perceive that there is no significant difference in effect among the direct cost variation groups. This signifies that stakeholders should consider all the groups while forecasting and controlling direct costs. The conclusion is that team-members have similar perception of the effect of factors on the direct cost variation, while construction factors, resources, and performance factors are most significant. It was also concluded that all the direct cost variation groups are all important in direct costs management. The study recommends that stakeholders should count on consultants and contractors for direct cost advice. Team-members should accommodate all the direct cost variation groups during cost management, with emphasis on site condition, site location, incorrect planning and poor financial control, interest rates, exchange rates, floor area, number of floors, materials availability, prices fluctuation, construction method, contract period, quality requirement, contractual procedure and bureaucracy in tendering which were the most significant factor from the direct cost variation groups.

\section{References}

Abraham, N. M. (2011), Functional Education, Militancy and Youth Restiveness in Nigeria's Niger Delta: The Place of Multi-National Oil Corporations (MNOCS). African Journal of Political Science and International Relations, 5(10), 442-447.

Achuenu, E. and Ujene, A. O. (2006), Evaluation of Labour and Material Costs in Building Elements in Nigeria. Nigerian
Journal of Construction Technology and Management,7(1), 99-110.

Al- Juwairah, Y.A (1997), Factors Affecting Construction Cost in Saudi Arabia. Unpublished Master thesis, King Fahd University of Petroleum and Minerals, Saudi Arabia. Available online;_http://eprints.kfupm.edu.sa/10044/

Ameh, O. J. and Shokumbi, B. B. (2013), Effectiveness of Non-Financial Motivational Scheme on Construction Workers Output in Nigeria. Ethiopian Journal of Environmental Studies and Management, 6 (3), 263-272.

Amusan, L .M. (2011), Study of Factors Affecting Construction Cost Performance in Nigerian Construction Sites. Unpublished Article, assessed from: http://eprints.Covenant university. edu.ng/121/1/COST_PERFORMANCE2.doc, date assessed 28/05/2011

Azhar, N., Farooqui, R. U. and Ahmed, S. M. (2008), Cost Overrun Factors in Construction Industry of Pakistan. First International Conference on Construction In Developing Countries (ICCIDC-I) "Advancing and Integrating Construction Education, Research \& Practice" August 4-5, Karachi, Pakistan

Ayeni, J.O. (1997), Principles of Tendering and Estimating. ( $2^{\text {nd }}$ ed.)Lagos: Builders Magazine.

Chitkara, K. K. (2006), Construction Project Management. Planning, Scheduling and Controlling. $11^{\text {th }}$ ed., New Delhi :Tata Mcgrawhill Publishing Company Limited.

Drew, D. S. and Lo, H. P. and Skitmore, R. M. (2001), The Effect of Client and Type and Size of Construction Work on a Contractor's Bidding Strategy. Building and Environment 36(3), 393406.

Eshofonie, F. P. (2008), Factors Affecting Cost of Construction in Nigeria. An Unpublished M.Sc. Thesis, Department of Building, University of Lagos, Akoka, Lagos, Nigeria

Ganiyu, B.O and Zubairu, I.K. (2010), Project Cost Prediction Model Using Principal Component Regression for Public Building Projects in Nigeria. Journal of Building Performance, 1(1), 21-28

Igben, J. L. (2012), Environmental Degradation and Occupational Dynamics of Labour Force in Delta State, Nigeria. Sacha Journal of Environmental Studies, 2 (1), 70-80

Juodis, A. and Stalioraitis, P. (2006), The Analysis of Statistical Characteristics of Construction Costs. Foundation of Civil and Environmental Engineering, 8, 60-71. 
Factors Influencing Direct Costs Dynamics of Building Projects................UJENE et al.

Memon, A. H., Rahman, I. A., Abdullah, M. R and Abdu Azis, A. A. (2010), Factors Affecting Construction Cost in Mara Large Construction Project: Perspective of Project Management Consultant. International Journal of Sustainable Construction Engineering \& Technology, 1(2), 41-54.

Omole, A.O. (1986), Causes of the High Cost of Building and Civil Engineering Construction in Nigeria. The Nigerian Quantity Surveyor, 6, 1-2.
Osei-Tutu, E. and Adjei-Kumi, T. (2002), The Cost Trend of Residential Housing Provision in Urban Areas of Ghana from 1991-2001. Building and Road Research Institute (BRRI), CSIR, Kumasi, Unpublished Paper. Retrieved from; http://www.auhf.Okeiweb.com/.../ ghana/construction-in-ghana.html.

Ujene, A.O. (2012), Dynamics of Direct Costs of Building Elements in South-South, Nigeria. An Unpublished Ph.D Thesis, Department of Building, University of Uyo, Nigeria. 